\title{
THE IDEOLOGICAL MEANINGS OF HERITAGE: THE CONFLICTING SYMBOLS IN YOGYAKARTA, INDONESIA
}

\author{
Johannes Parlindungan Siregar \\ PhD Candidate at Queensland University of Technology, Australia \\ Department of Regional and Urban Planning, Brawijaya University, Indonesia \\ ORCID ID: https://orcid.org/0000-0003-0266-3839 \\ Email: johannes@ub.ac.id
}

\begin{abstract}
The heritage of Yogyakarta is always situated in a dynamic urban environment. Heritage conservation has been challenged by a lack of understanding on the ideological process in the creation of meanings. This paper investigates the creation process of urban space that is currently appreciated as heritage. The paper uses the city of Yogyakarta as the case study because its uniqueness as a mix of traditional and colonial cities. The study uses the concept of meaning production to understand the association between the construction of urban space and ideological meanings. This concept corresponds to the creation of urban objects and the recognition of meanings in the society. This study uses data sourced from a literature study. As the result, the process of meaning production has demonstrated social and political forces in the construction of traditional and colonial buildings. Situation in the past demonstrates urban space as a tool of political hegemony of traditional court and colonialist. A different social milieu in the present day changes the conflicting ideologies into history. Therefore, the urban structure expresses political strategies of relevant authorities in proclaiming hegemony and regulating society. This study provides a basis for investigating the influence of ideologies on the meaning of heritage that corresponds to cultural significant.
\end{abstract}

Keywords: Urban heritage; meanings; socio-semiotics; historical memories; traditional philosophy; ideology.

\section{INTRODUCTION}

The understanding about heritage is not complete without recognising ideological meaning embedded in the construction of physical representation. Particularly in a city, the physical representation of heritage is manifested in monuments, historic buildings and urban form. This paper raises an inquiry about meanings associated with the creation and recognition of symbolical meanings in urban space. The study is crucial in urban context, since a city has a dynamic environment in which social, cultural, and political aspects are interwoven in the creation of urban space that influence the meanings. Therefore, the historic city should be concerned, not only as a mere physical object, but also as the representation of culture and ideology.

The research takes Yogyakarta as a case study. This city is located in the Central Java region, Indonesia. Yogyakarta was founded as a Kingdom called Ngayogyakarto Hadiningrat in 1755 (Handinoto, 2015). The city of Yogyakarta is considered relevant as a case study because this city represents the mix of traditional and colonial cities. The presence of this combination is essential to reveal different ideological meanings symbolised by buildings and urban structure.

Literature study argues that the uniqueness of a historic city contributes to place identity associated with the uniqueness of physical features and meanings (Cheshmehzangi, 2012). However, there is a limited account on the ideological aspect of urban space construction contributing to the historical significance. However, some studies have concerned on the reflection of cultural representation and ideology on the buildings and city design. The influence is obvious in countries with strong cultural practices, as exemplified in Asian countries. For example, a study found that Chinese cities reflected traditional geomancy (Yoon, 2017). In this case, philosophy was an essential part of city design. According to this research, the current developers in China used geomancy to design their properties. Another study demonstrated the architect's influence on building designs in western countries. A study — conducted in Yugoslaviafound that some prominent architects express structuralist ideology on their design. The ideology was reflected through functionalist principles and modernity values (Stojiljković \& Ristić Trajković, 2017). The most recent study demonstrated the representation of ideology - the power relation - in a historic urban centre of Bantul city, Indonesia (Isnaini, 2016). Despite the association between architectural objects and meanings, these studies did not demonstrate the relationship with the ideological process of urban space development, especially relating to a contradiction between narratives created by the colonised society and the colonialist. This problem becomes 
more crucial in a post-colonial society. This situation creates a knowledge gap about the ideological conflict between the traditional and colonial representations, as reflected in the city design. Therefore, the result of this study is expected to refine the understanding about cultural significance by drawing attention to the construction of urban space and the production of meaning.

This paper uses the concept of meaning production to investigate relationship between the physical construction of urban space and the ideological meanings in Yogyakarta. This approach considers the recognition of meaning as an integral part of the social and political process of space construction (Gottdiener, 1995). Further, the analysis occurs in three areas. First, the analysis of meaning production elaborates the construction of prominent urban structures as the representation of ideology. Second, the analysis of meaning recognition investigates the meanings of heritage recognised in the present day as endorsed by heritage conservation. In this stage, the urban heritage of Yogyakarta is recognised as the representation of traditional philosophy and historical memories. Finally, the study demonstrates ideological conflicts between traditional and colonial epochs in the past. The conflict is still present today in the society through heritage conservation. Alongside the cultural and historical accounts, the representations are also currently used as tourism commodity. This situation expresses the creation of contemporary representations.

This paper uses literature study to compile and analyse historical data about the city in the colonial period along with relevant social and political situations. Although the study involves historical accounts, it does not investigate the sequence of political change and its implication on Yogyakarta's urban structure. Instead, it studies the city design in the colonisation period, and reflects the meanings in the present day.

The paper is delivered in three parts. After the introductory section, the paper firstly elaborates the methodology. It discusses the analysis and literature relevant to the concept of meaning production and recognition. This section provides a frame to the overall analysis. The third section connects the meaning production and recognition in revealing the overarching ideologies and its implication on heritage.

\section{METHODOLOGY}

This paper demonstrates a literature study about the history of Yogyakarta and symbolical meanings of monumental buildings with a more focus on the area surrounding philosophical axis (the area between Tugu and Panggung Krapyak monuments). The analysis used socio-semiotic approach as proposed by Gottdiener (1995). In this approach, architectural objects were presumed as signifier and meanings are signified. Another important aspect of this approach was the use of socio-political context to reveal a rationale for the creation of architectural objects and the recognition of meanings. In this sense, the creation of architectural objects, or heritage, was presumed as the production of meanings because the objects immediately express the historical and cultural narratives. Consequently, this paper suggests the sociopolitical context as the ideological meanings of heritage.

Gottdiener argues that the presence of meanings is in line with the space construction (Gottdiener, 1995). Further, Lagopoulos (1986) supports this concept by proposing three aspects, such as the 'socioeconomic production of real space, political production of space and ideological production of space'. The first aspect corresponds to the construction of physical space. Social and political power influences this aspect through market and political policy. The second aspect involves institutional power. The intervention of governmental institutions or social bodies in urban development resembles this aspect. The last aspect generates meanings on the basis of the social, cultural, and political context of society.

Another important aspect of semiotics is the recognition of meanings. Symbolism has essential role to the meanings especially in the construction of place (Cheshmehzangi, 2012). Additionally, Kusno argues that physically built environment represents the 'visually perceptible form' (Kusno, 2010). This character enables an architectural structure to express a symbolic meaning.

The application of this approach was crucial, especially relating to social life in a city. This study made an effort to elaborate the process of urban space development in the past as a basis for historical and cultural significances in the present day. The investigation used historical study to reveal the initial city design of Yogyakarta. The next section elaborates the creation of symbolic objects and the recognition of meanings of Yogyakarta heritage.

\section{RESULTS AND DISCUSSION}

\section{The Production of Meanings in Urban Space}

Symbolic objects exist in urban space through the creation and development of urban space. The symbols were created during the early development 
of Yogyakarta in the colonial period, or the time between 1755 and 1945. The year 1755 marks the foundation of Yogyakarta and 1945 refers to the declaration of Independence of Indonesia. The study, therefore, proposes the term 'historical period' reference to this time span.

Development in Yogyakarta urban centre expresses different ideologies. In this case study, the authorities correspond to central agents with a power to impose the construction of symbolic objects. The study proposes two epochs in associating with the historical period, i.e. traditional and colonial epochs. The epochs express different ideologies representing political power through symbolic objects. The former uses traditional cosmology to create order in urban structure and society. The order is made on the basis of feudalism and the traditional way of life. On the other hand, the latter imposes imperialism and competes against symbols of the former.

The foundation of Yogyakarta in 1755 starts the traditional epoch indicating the creation of traditional symbols in physical objects, such as monuments, buildings, and traditional urban structure. It is the age when people tightly practised the traditional way of life and religion. At that time, people's attitudes and actions reflected traditional spirituality, mysticism and morality (Herusatoto, 2001).

In the ancient kingdom of Yogyakarta, Sultan reigned using his mystical and political influences as a spiritual leader - the caliph - and the caretaker of the universe (Karsono \& Wahid, 2008). The first Sultan of Yogyakarta implemented two cosmological concepts as the basis of the city design (Suryanto, Ahmad, \& Sudaryono, 2015). Figure 1 depicts the configuration of objects representing the cosmology. The map shows the situation in 1925. The cosmological concepts correspond to the philosophy of traditional religion, which is an acculturation between the teachings of Hindu and Islam (Karsono \& Wahid, 2008). This acculturation is represented by the southnorth cosmology of Hindu; meanwhile the configuration of Catursagatra comprised of mosque, Kraton and Alun-Alun represents the influence of Islam (Isnaini, 2016; Wardani, Soedarsono, Haryono, \& Suryo, 2013). In this case, mosque is located to the west of Alun-Alun to compromise on kiblah direction.
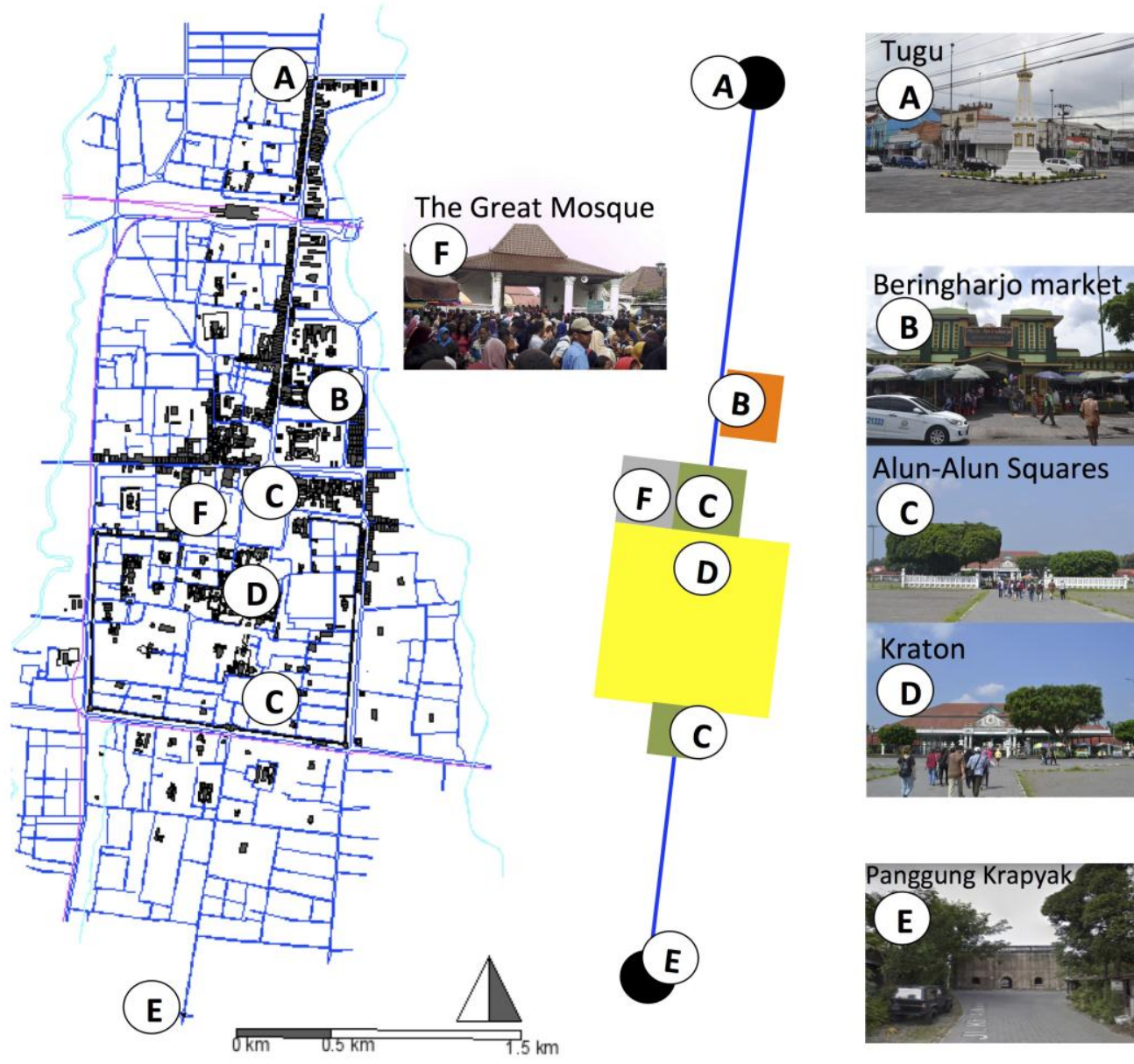
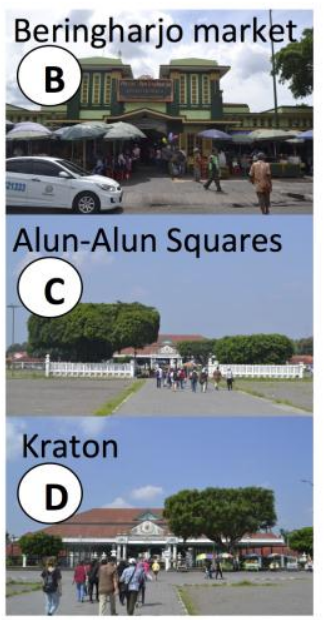

Elements of

philosophical axis:

1. Tugu Monument

2. Kraton

3. Panggung

Krapyak

Monument
Elements of Catursagatra:

1. Keraton

2. The Great Mosque

3. Beringharjo Market

4. Northern AlunAlun Square

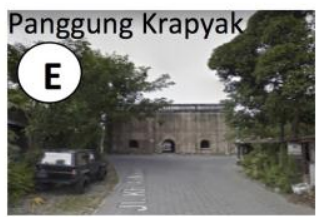

Fig. 1. The Representation of Traditional Philosophy in the City Design (Source: adapted from (Yunus, 1991). Photos are author's documentation) 
The first cosmological concept is philosophical axis. The representation of this concept is the southnorth axis in the urban centre. Through a map observation, the axis is not in straight directions to south and north poles, but it is slightly tilted to the east. The south-north direction is associated with the location of South Ocean and Mount Merapi as the main geographical orientations in Javanese cosmology. Panggung Krapyak monument is located in the southern area, expressing the South Ocean and Tugu monument is situated in the northern area, expressing the Mount Merapi. In addition to this, the palaceKraton - is placed in between (Suryanto, et al., 2015). Kraton acts as imago mundi representing the absolute and mythical power of the Sultan (Behrend, 1989). The philosophical axis represents a philosophy known as Manunggaling Kawula Gusti. This philosophy encourages the unity between the leader and the people. The second concept is Catursagatra. This concept situates kraton, mosque, traditional square, and market in a contiguous position. Catursagatra has an association with a philosophy called Мemayu Hayuning Bawono. It reflects Sultan as a supreme leader of the society implementing a leadership based on spirituality, economy, and culture.

The creation of traditional symbols occurs coincidently with the colonisation associated with the colonial epoch. This epoch indicates the production of colonial structures expressing the involvement of colonialist in the early development of Yogyakarta (see Figure 2). The political intervention of colonial authority was firstly manifested in the foundation of Yogyakarta through the initiation of the Gayanti Treaty in 1755 (Luthfi, Nazir, Tohari, Winda, \& Tristiawan, 2014). Through this treaty, the colonialist tried to split the Mataram Kingdom into two smaller kingdoms: Ngayogyakarto Hadiningrat - the current Yogyakarta - and Surakarta.

Colonialist influenced the city design by implementing the concept of 'new Hindia city' (Handinoto, 2015). This concept was manifested through the presence of assistant resident office - the office of colonial authority - located near the northern traditional square, Alun-Alun Lor. In 1765, the Dutch authority built a colonial fortress located in the northern area of Kraton. Following this - in 1887-a

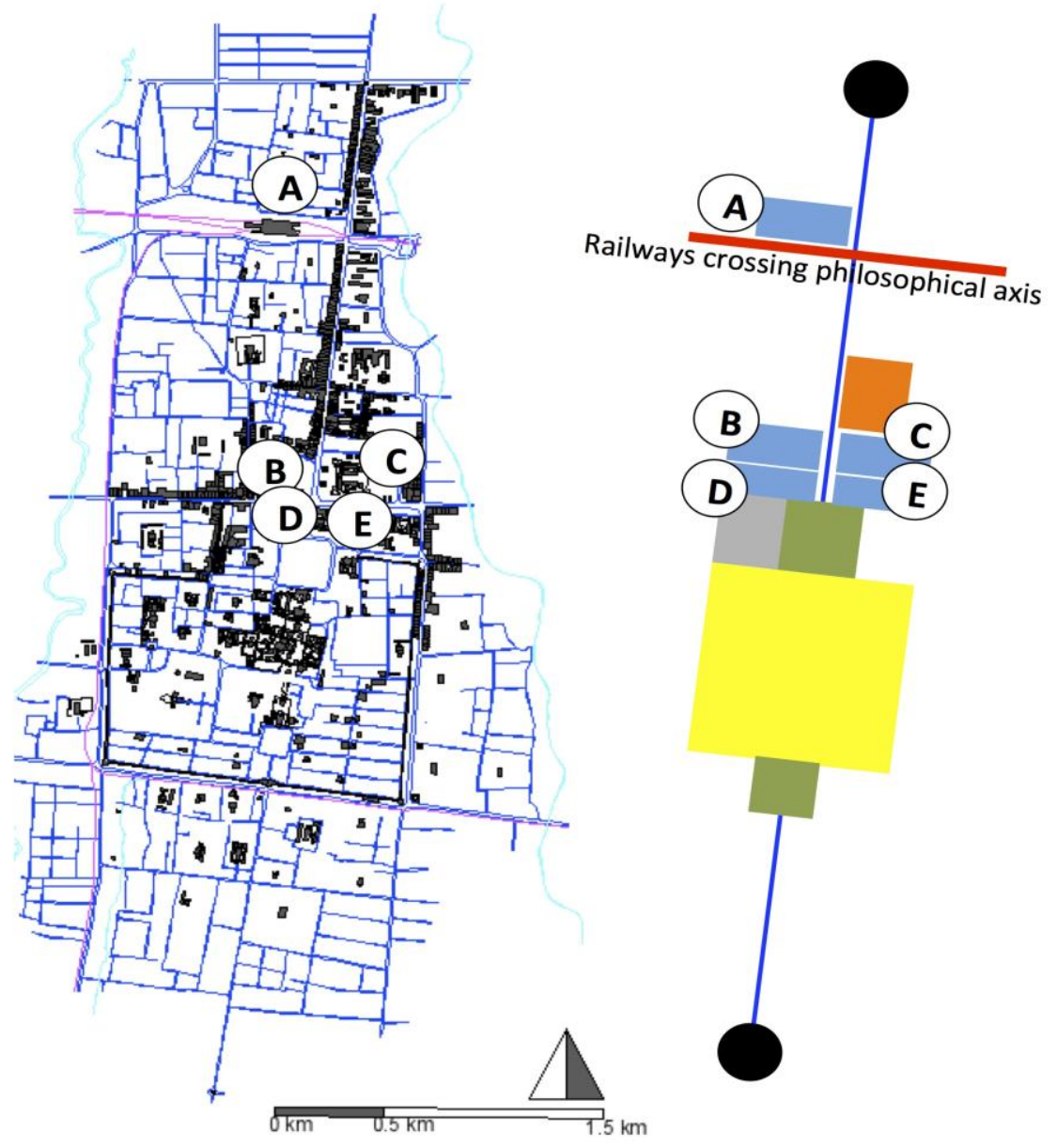

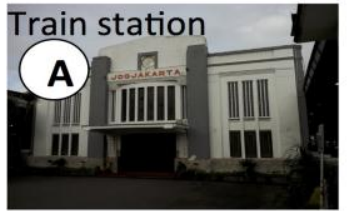
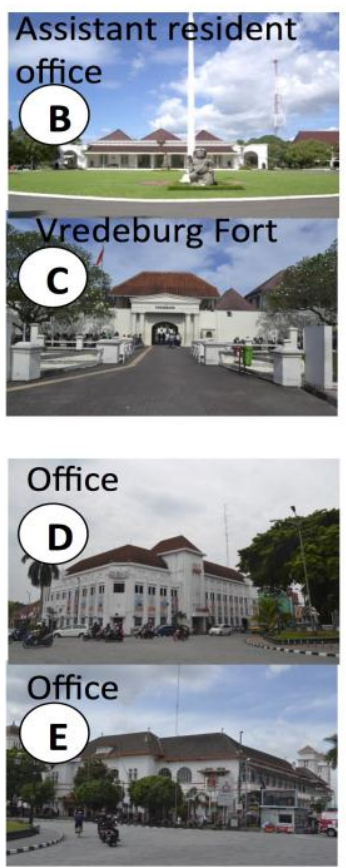

Fig. 2. Monumental Colonial Buildings Surrounding the Philosophical Axis (Source: adapted from (Yunus, 1991). Photos are author's documentation) 
train station was built on Malioboro Street, between Tugu Monument and Kraton (Karsono \& Wahid, 2008). The construction of these objects aimed at diminishing the relevance of traditional symbols (Kusno, 2012). It also started the era of industrialisation in Yogyakarta (Yunus, 1991). The locations of these objects are shown in Figure 2. Another form of colonial intervention in Yogyakarta was the implementation of the ethnic politic called Wijkenstelsel in 1862 (Handinoto, 2015). This policy made people settled in residential clusters according to their ethnicity. Using this policy, the colonialist applied social control over the society. The physical and social consequences of this regulation were the presence of ethnic settlements and social segregation.

In the early twentieth-century, Dutch authority applied a different policy. This new policy was called ethical policy. It promoted an appreciation for tradition of the colonised society. As a response of this policy, a few Dutch architects introduced an archi- tectural movement. They did not agree with social and cultural disintegrations made by the colonialist. Instead, this group promoted cultural uniqueness of the colonised society through an architectural style, called the Indische Style (Veenendaal, 2015). The ideas of this movement were to reject the universal style of the colonial architecture and combine the Western standard with the local architectural tradition. This movement aimed at gaining cooperation with the local society in a peaceful way and strengthening the colonial economic growth (Kusno, 2014). Through this cultural strategy, the superiority of the imperialist was sustained.

The situation has changed in the present day Yogyakarta. In the Independence era, Yogyakarta is ruled in a decentralised governmental system. The new government develops the city following the national development agenda. Right after Indonesia gained its independence in 1945, the central govemment developed the northern area as an educational

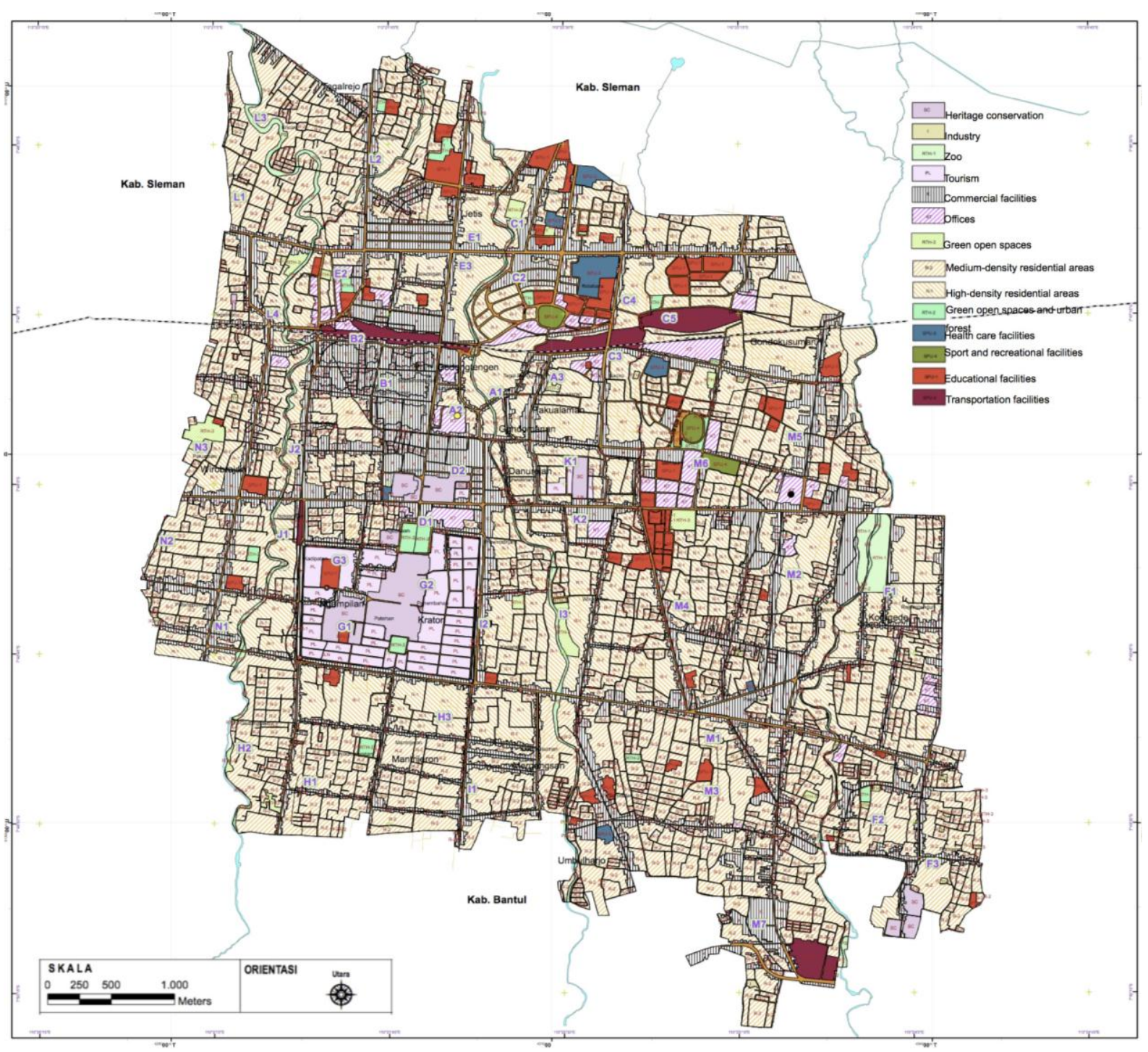

Fig. 3. The Current Land Uses of Yogyakarta Urban Centre (Source: Yogyakarta (2015)) 
zone (Yunus, 1991). A state university - the Gadjah Mada University - was established in this area. Figure 3 shows location of the educational area. In the following years, other educational facilities - schools and universities - have been continuously founded. In 2015, Yogyakarta had 37 higher degree education institutions; comprising of 6 universities, 13 educational institutes, and 18 polytechnics (Jogjakota.go.id, 2015). Consequently, this region has gained a national reputation as the centre of education.

Currently, the local government uses an urban planning scheme to regulate the urban development. The latest urban plan is regulated in 2015 (Yogyakarta, 2015). This urban plan designates the Kraton as a historic and tourism area (see Figure 3). The northern section of philosophical axis-Malioboro and Mangkubumi Streets - is the main comercial zone. On the other hand, the southern section of the philosophical axis-Panjaitan Street - is a residential zone.

In this period, both central and local governments protect the heritage, i.e., the representations of traditional philosophy, and colonial buildings. The principal regulation is Cultural Heritage Act number 11/2010 (Indonesia, 2010). In addition, the local government expresses a specific concern for protecting the philosophical axis as regulated in Provincial Regulation number 6/2012 (Yogyakarta, 2012). These regulations recognise heritage values and the use of heritage as educational and economic resources, as well as national and regional identities. Therefore, the current government contributes to the reproduction of old urban area as contemporary cultural and economic resources.

\section{The Recognition of Meanings in Urban Space}

In general, the heritage of Yogyakarta expresses two meanings: traditional philosophy and historical memory. Each meaning has an association with the epochs. The traditional epoch produces the representations of traditional philosophy. On the other hand, the combination of colonial and traditional epochs produces historical memory about the historical growth of Yogyakarta and the colonisation. In this sense, the creation of traditional symbols and colonial structures represent the development stages of the city and conflicting ideologies between both traditional court and colonial rulers.

Regarding the traditional philosophy, the exposure to philosophical axis and Catursagatra allows people to contemplate and comprehend the world. Meliono asserts that the symbols embed meanings in social system and encourage people to behave following the philosophy (Meliono, 2011). Traditional symbols are essential in Javanese society because of two reasons. Firstly, the symbol is a medium for inheriting traditional thought through generations (Herusatoto, 2001). Further, the traditional thought corresponds to a set of ideas representing wisdom and traditional teachings. The wisdom and teachings form a deep foundation in a traditional society (Soedigdo, Harysakti, \& Usop, 2014). It also represents the ethnic consciousness contributing to the 'ethnic identity' (Meliono, 2011). Secondly, the traditional teaching is essential for the development of personal character. This characteristic is distinct in the Javanese society. The perspective and behaviour of the Javanese people stem from their religion, morality, and mysticism (Herusatoto, 2001). Traditional structures and monuments in Yogyakarta urban space represent a reminder of traditional teachings and the ways of life. Through the presence of these structures, people are able to recall information about how to behave and conduct their life in good manners. As mentioned earlier, the physical representations of the philosophical axis and Catursagatra evoke the awareness of Manunggaling Kawula Gusti and Memayu Hayuning Bawono.

The recognition and internalisation of traditional philosophy primarily involve city inhabitants. The people are the central agents in the recognition of traditional symbols. The symbols aim at connecting people to the spiritual world reaching the 'absolute balance' or harmony (Rianingrum, Sachari, \& Santosa, 2017). Therefore, the narratives created in the urban space are meaningful for local people as the intangible feature of heritage (Malpas, 2008; Su, 2018).

The historical memory reflects meanings in a different way. While traditional philosophy involves spontaneous perception and people's recognition for the tradition, the historical commemoration requires the involvement of government in confirming historical value and heritage. The notion 'heritage' is present in the current society to celebrate the memories of colonisation, independence war and cultural achievements. Fitri, Ahmad, and Ahmad (2015) assert that the concept of heritage conservation adopted in Indonesia has the same root as in the international heritage conventions. This concept implies heritage as a form of authorised discourse created by government. The government adopts this concept in national platform as regulated in the Cultural Heritage Act number 11/2010.

Yogyakarta urban centre is a historic promenade representing historical values and memories. This situation makes physical character an essential 
element in heritage conservation (ICOMOS, 1987). In this sense, the historic buildings and monuments represent cultural significance - a set of values that made heritage important (Fredheim \& Khalaf, 2016). Historic buildings of the philosophical axis, Catursagatra, and colonial buildings altogether form a chain of memory related to the history of Yogyakarta and the independence war.

The current heritage act legitimises the involvement of government in regulating the use of heritage as a representation of identity, an educational resource, and an economic potential. The government has an intention to promote the identity or local distinctiveness to different levels, such as the local, national and international levels. This action aims at gaining popularity and economic benefits through heritage tourism (Loulanski \& Loulanski, 2011).

Heritage regulation enables the government to form a team of experts and initiate the assessment and conservation programs (Indonesia, 2010). Additionally, the local government of Yogyakarta also cooperates with the social communities and NGOs (Suryanti, Sumartono, \& Hermawan, 2014). Consequently, the heritage conservation tasks involve the academic, administration, and decision-making processes in making documentation, registration, assessment and plan.

\section{The Ideological Associations of Heritage}

The creation of urban space and meanings express the prevalent ideologies. In the historical period, the traditional and colonial symbols represent a contradiction between the freedom and colonisation. In the present day, the government reproduces the contradictive narrative as history. Through this way, the current society appreciates urban heritage as identity, the traditional way of life and an economic resource.

The study found that the traditional symbols in Yogyakarta are produced in a process called 'Asiatic mode of production' (Lagopoulos, 1986). This mode of production is particular in traditional Asian societies where social process is dominated by the political and mythical rules of a King. Therefore, Sultan and the court are central to the society and represent the centre of universe (Behrend, 1989). The traditional society of Yogyakarta strongly holds traditional belief. Hindu tradition teaches symbolism associated with the geographical features such as mountain and ocean as the representation of deities and the transcendent world. In addition, Islamic tradition implies the role of a man as a spiritual leader in the world. Consequently, the presence of mosque is essential to the urban structure. The combination of the two beliefs endorses the political and spiritual power of Sultan as a supreme leader establishing harmony between humans and God, humans and the universe, and humans in their social relations. The first Sultan of Yogyakarta uses cosmological symbols in the city design to articulate his political interest and the supremacy of the elite class as also argued by Purwani (2017). In the two cosmologies, philosophical axis and Catursagatra, Kraton is located in the central area emphasising the court supremacy. This case reflects a hegemonic function of the symbol (Bennett, 1981b) and the use of architecture as a power apparatus (Mouffe, 1981).

The use of traditional symbols in the formation of Yogyakarta urban centre is essential because of two reasons. Firstly, the traditional urban structures prolong Javanese philosophies: Manunggaling Kawula Gusti and Memayu Hayuning Bawono. The philosophies encourage the society to live in order with a deep spirituality and a trust to the leader. Through this way, the social bond can be created. Secondly, the central position of Kraton in philosophical axis represents the hegemony of Sultan and feudalism. This symbolism is critical in the colonial period because the philosophy also teaches people to unity with Sultan in facing colonialist. In addition, the feudalism also puts people in a social order. Therefore, the traditional symbols - traditional monuments, squares, buildings and traditional urban structure - is politically important to strengthen the society through traditional teachings and promote an opposition to colonialist.

Regarding social order, the royal elite of Yogyakarta acts as a 'leading' group. Bennett (1981b) argues that this kind of group demonstrates a cooperative way in developing the society by uniting people under a common perspective that usually has a strong basis on local culture. In this sense, the court creates conducive situation to a harmonious and peaceful society. Again, the traditional urban structure symbolises philosophies relevant to this societal situation. In a traditional society of Yogyakarta, the society reflects a high attachment to this hegemonic influence because the mythology of the Sultan is an integral part of the Javanese tradition. The feudalistic system and traditional philosophy correspond to both the ideology and belief system of the society (Bennett, 1981a). Kraton and tradition are institutions delivering the order into the society and materialising their ideas in the physical symbols of the city design.

On the other hand, the colonial representations - military facilities, colonial offices, colonial buildings, and other colonial structures-express 
political intentions of the colonial authority. Regarding the mode of production, Lagopoulos in his chapter does not provide an idea about how the imperialism influences social process and symbolism in the Asiatic mode of production (Lagopoulos, 1986). In fact, the city is formed by the mix between traditional and colonial forces as evidenced in this study.

Colonial military area is intended to face Java War and suppress Sultan's authority (Karsono \& Wahid, 2008). The court reacts to this action by protecting Kraton with high walls and a fortress. This condition demonstrates a conflicting situation between the colonialist and the court. The presence of ethnic settlements also demonstrates a political conflict by which the colonialist made effort to disunite the colonised society and applied a strict social control. Another form of cultural assault is the construction of railways crossing on Malioboro Street as depicted in Figure 2. This action obviously neglects the hegemonic symbol of both the court and local tradition.

Along with the colonisation, Dutch authority also introduces modernity and industrialisation in the city. In this period, the colonial authority constructed modern roads and railways to support sugar industries, economy, and people mobility (Goenawan \& Harnoko, 2012). Through this way, the colonialist try to represent the Western as the leader of indigenous society (Veenendaal, 2015). This situation strengthens the hegemony of colonialist in dominating the colonized society. As argued by Bennet, the domination is present by disconnecting the local society from its traditional ideology and cultural root (Bennett, 1981b). In this case, modernity expresses an opposetion to tradition. The rationalistic thought brought by modernity makes people indifferent to mythology and traditional philosophy.

Situation in the past reflects the use of architectture as the representation of authority. The involvement of architecture in political praxis is possible as argued by Isnaini (2016). In Yogyakarta, the presence of traditional and colonial symbols in the same place and at the same time demonstrate a competition to conquer social and political realms. Both parties use different approaches to winning the competition. The court uses traditional symbols to lead the society; meanwhile, the colonialist uses the domination strategy. The first group attempts to unite the society and the second one does the opposite thing. This situation leads to a political conflict about striving to gain freedom from the dominating group. Consequently, the representations of traditional court and colonialist bring memories about the independence war and evoke nationalism.
In the present time, different social context attaches new meanings to the representations of the past. Political conflicts in the past are currently remembered as history, while relevant objects to the history are appreciated as heritage. This kind of memory corresponds to the common identity contributing to the spirit of nationalism (Storm, 2012). The ideas of history and nationalism mediate conflicts between the traditional and colonial representations. Using heritage act, the government legitimises heritage as a representation of history and cultural uniqueness. This situation implies that the current social institutions and settings contribute to the change of meaning (Zancheti \& Loretto, 2015).

Traditional and colonial representations are currently recognised as heritage. The government has an intention to deliberately confirm the status of heritage, since the objects are prominent buildings in the city and have an association with the national culture and history. In this sense, the historic and cultural objects resemble the 'heritage by designation' (Tweed \& Sutherland, 2007). Moreover, this situation reflects the political role of the government as a leading institution in heritage conservation. The government tries to succeed in developing the nation by attaching the society to its cultural and historical foundations. The current authority demonstrates its ability to create a new discourse about history by changing the tension between traditional court and colonialist into history and heritage. Again, this action expresses government as a leading agent by uniting society behind common memory and cultural particularity.

The current society uses heritage as the symbol of identity and nationalism. The identity reflects the uniqueness of Yogyakarta and its potential for tourist attraction. The status of heritage also gives a chance for private sector to involve in the tourism industry and their related economic activities. As a consequence, heritage is currently consumed as an economic commodity alongside its symbolic function as historical and cultural representations.

This study contributes to a new understanding about heritage as a discourse. The discourse is a political product of relevant authorities. The discourse of heritage should be understood by incorporating the process of urban development into the analysis. The investigation of this process reveals not only the historical account, but also ideological meaning. This understanding is useful to deepen historical knowledge not only about the particularity of historical buildings, but also narratives about political situation in the past that makes heritage significant. In addition, the analytical concept of this research can also be used 
to anticipate the change of meaning in the contemporary situation and avoid the loss of cultural significance of heritage. This approach is essential to the conservation because it expresses the narratives associated with social context in the time of construction and the creation of urban space. This concept allows people to understand the city uniqueness; not only in a frame endorsed by heritage conservation policy, but also the complete historical and cultural narratives of the city and society. Although the change of meaning is inevitable, the historical narratives can still be recalled.

\section{CONCLUSION}

The era before the declaration of Independence comprised both the traditional and colonial epochs. Each epoch uses different physical symbols to express relevant ideological intentions. The traditional epoch demonstrates the implementation of traditional philosophies, such as the philosophical axis and Catursagatra. These philosophies had two manifestations: 1) forming the traditional configuration of the city, and 2) the traditional way of life. The local authority uses the traditional symbols to maintain the hegemonic influence of the Sultan as a spiritual and political leader.

The colonial authority imposes its influence by interrupting local symbols. In this case, the colonialist interrupted the philosophical axis and developed the military area. As a consequence, Yogyakarta also represents the character of a colonial city. The introduction of Dutch architecture and modern infrastructure is also an effort to promote the Dutch as the civilisation's leader.

The traditional and colonial epochs reflect different approaches in the creation of meanings. This situation has led to the ideological and cultural conflicts occurring in the past. In the present day, the conflicts are remembered as history and the physical representations are conserved as heritage and national identity. The current society uses heritage as a traditional symbol and the representation of nationalism. These two meanings also have an economic potential as regulated by the current heritage policy.

The investigation suggests that creation and recognition of meanings connect different periods through the creation and the use of symbols. The two processes reflect the ideologies of relevant authorities and societies. The meanings have an association with the ideological intentions and conflicts before the independence. This approach is essential to cultural significant especially the one related to historical narratives. Hence, the study contributes to the development of discourse analysis about heritage and the influence of relevant authorities on the narratives. The study recommends further study on the perceived meaning of Yogyakarta. This further study will be important to reveal the actual perceived meaning from the perspective of urban space users.

\section{ACKNOWLEDGEMNT}

This work was carried out through a scholarship from the Indonesia Endowment Fund for Education (LPDP) administered by the Government of the Republic of Indonesia.

\section{REFERENCES}

Behrend, T. (1989). Kraton and cosmos in traditional Java. Archipel, 37(1), 173-187.

Bennett, T. (1981a). Antonio Gramsci: Culture. In T. Bennett, G. Martin, C. Mercer \& J. Woollacott (Eds.), Culture, ideology and social process: A reader (193-196). Great Britain: The Open University.

Bennett, T. (1981b). Antonio Gramsci: Hegemony. In T. Bennett, G. Martin, C. Mercer \& J. Woollacott (Eds.), Culture, ideology and social process: A reader (197-198). Great Britain: The Open University.

Cheshmehzangi, A. (2012). Identity and public realm. Procedia-Social and Behavioral Sciences, 50, 307-317. doi:10.1016/j.sbspro.2012.08.036

Fitri, I., Ahmad, Y., \& Ahmad, F. (2015). Conservation of tangible cultural heritage in Indonesia: A review current national criteria for assessing heritage value. Procedia-Social and Behavioral Sciences, 184, 71-78. doi:10.1016/j.sbspro.2015. 05.055

Fredheim, L. H., \& Khalaf, M. (2016). The significance of values: Heritage value typologies reexamined. International Journal of Heritage Studies, 1-17.

Goenawan, R., \& Harnoko, D. (2012). Mobilitas sosial Daerah Istimewa Yogyakarta periode awal abad ke-20: Suatu kajian sejarah sosial. Yogyakarta: Ombak publisher.

Gottdiener, M. (1995). Postmodern semiotics: Material culture and the forms of postmodern life. USA: Blackwell.

Handinoto (2015). Perkembangan kota di Jawa abad $X V I I I$ sampai dengan pertengahan abad XX. Yogyakarta: Ombak Publisher.

Herusatoto, B. (2001). Simbolisme dalam budaya Jawa. Yogyakarta, Indonesia: Hanindita Graha Widia. 
ICOMOS. (1987). Charter for the conservation of historic towns and urban areas. Washington, USA: Washington, DC: Adopted by ICOMOS General Assembly. Act number 11/2010: Benda cagar budaya (2010).

Isnaini, S. (2016). Membaca kota, mengurai relasi kuasa. Yogyakarta: Penerbit Andi.

Jogjakota.go.id. (2015). Data pendidikan. Yogyakarta: The municipality of Yogyakarta Retrieved from http://investasi.jogjakota.go.id/id/more/ page/21/Data-Pendidikan.

Karsono, B., \& Wahid, J. (2008). Imaginary axis as a basic morphology in the city of YogyakartaIndonesia. Paper presented at 2nd International Conference on Build Environment in Developing Countries, Penang, Malaysia.

Kusno, A. (2010). The appearances of memory : Mnemonic practices of architecture and urban form in Indonesia. Durham: Duke University Press.

Kusno, A. (2012). Zaman baru generasi modernis. Yogyakarta: Ombak Publisher.

Kusno, A. (2014). Behind the Postcolonial: Architecture, Urban Space and Political Cultures in Indonesia. Florence: Taylor and Francis.

Lagopoulos, A. (1986). Semiotic urban space models and modes of production: A socio-semiotic approach. In M. Gottdiener \& A. Lagopoulos (Eds.), The city and the sign: An introduction to urban semiotics (176-201). New York: Columbia University Press.

Loulanski, T., \& Loulanski, V. (2011). The sustainable integration of cultural heritage and tourism: a meta-study. Journal of Sustainable Tourism, 19(7), 837-862. doi:10.1080/09669582.2011. 553286

Luthfi, Nazir, Tohari, Winda, \& Tristiawan. (2014). Keistimewaan Yogyakarta yang diingat dan yang dilupakan. Yogyakarta: Ombak Publisher.

Malpas, J. (2008). New media, cultural heritage and the sense of place: Mapping the conceptual ground. International journal of heritage studies, 14(3), 197-209. doi:10.1080/135272508019 53652

Meliono, I. (2011). Understanding the Nusantara thought and local wisdom as an aspect of the Indonesian education. Tawarikh - International Journal for Historical Studies, 2(2).

Mouffe, C. (1981). Hegemony and ideology in Gramsci. In T. Bennett, G. Martin, C. Mercer \& J. Woollacott (Eds.), Culture, ideology and social process: A reader (219-234). Great Britain: The Open University.
Purwani, O. (2017). Javanese cosmological layout as a political space. Cities, 61, 74-82.

Rianingrum, C. J., Sachari, A., \& Santosa, I. (2017). Representation of harmony in Javanese Culture in building design of Kauman Yogyakarta. GSTF Journal of Engineering Technology (JET), 3(2).

Soedigdo, D., Harysakti, A., \& Usop, T. B. (2014). Elemen-elemen pendorong kearifan lokal pada arsitektur nusantara. Jurnal Perspektif Arsitektur, $9(1)$.

Stojiljković, D., \& Ristić Trajković, J. (2017). Semiotics and urban culture: architectural projections of structuralism in a socialist context. Social Semiotics, pp.1-19. doi:10.1080/10350330.2017. 1300084

Storm, E. (2012). The birth of regionalism and the crisis of reason: France, Germany and Spain. In J. Augusteijn \& E. Storm (Eds.), Region and State in Nineteenth-Century Europe (36-54). New York: Springer.

$\mathrm{Su}$, J. (2018). Conceptualising the subjective authenticity of intangible cultural heritage. International Journal of Heritage Studies, 24(9), 919-937. doi:10.1080/13527258.2018.1428662

Suryanti, E., Sumartono, S., \& Hermawan, H. (2014). Culture development planning in the Special Region of Yogyakarta: Management planning of cultural heritage in Kotagede District based on community empowerment conservation model. Journal of Indonesian Tourism and Development Studies, 2(3), 120-128.

Suryanto, Ahmad, D., \& Sudaryono. (2015). Aspek budaya dalam keistimewaan tata ruang Kota Yogyakarta. Jurnal Perencanaan Wilayah dan Kota, 26(3), 230-252. doi:10.5614\%2Fjpwk. 2015.26.3.6

Tweed, C., \& Sutherland, M. (2007). Built cultural heritage and sustainable urban development. Landscape and urban planning, 83(1), 62-69.

Veenendaal, A. (2015). Building modernity. Indische architecture and colonial autonomy, 1920-1940 Bachelor. Utrecht University, the Netherland.

Wardani, L. K., Soedarsono, R., Haryono, T., \& Suryo, D. (2013). City heritage Of Mataram Islamic Kingdom In Indonesia. Case study of Yogyakarta Palace. The International Journal of Social Sciences, 9(1), 104 - 118.

Provincial Regulation number 6/2012: The conservation of cultural heritage (T. P. G. o. Yogyakarta) (2012).

Municipal Regulation number 1/2015: The detailed spatial plan and zoning regulation (T. M. G. O. Yogyakarta) (2015). 
Yoon, H.-k. (2017). Chinese geomancy and traditional urban design. Journal of Urban Design, 22(6), 735-737.

Yunus, H. S. (1991). The evolving urban planning: The case of the city of Yogyakarta. Indonesian Journal of Geography, 21(61), 1-14.
Zancheti, S. M., \& Loretto, R. P. (2015). Dynamic integrity: A concept to historic urban landscape. Journal of Cultural Heritage Management and Sustainable Development, 5(1), 82-94. Retrieved from ProQuest Central. doi:10.1108/JCHMSD03-2014-0009 